\title{
PERANCANGAN KONTEN VISUAL SEBAGAI MEDIA PROMOSI PADA SOSIAL MEDIA INSTAGRAM KAFE REGINA DI KABUPATEN TULUNGAGUNG
}

\author{
Anastasia Jovita Paskalina ${ }^{1}$, Aditya Nirwana ${ }^{2}$, Didit Prasetyo Nugroho ${ }^{3}$ \\ Program Studi Desain Komunikasi Visual, Universitas Ma Chung \\ Email : 331710005@student.machung.ac.id, aditya.nirwana@machung.ac.id, \\ didit.nugroho@machung.ac.id
}

\begin{abstract}
Abstrak
Dengan adanya peningkatan pembangunan kafe di area Jawa Timur khususnya Kabupaten Tulungagung, kompetitor semakin meningkat sehingga mengharuskan para pemilik usaha kafe memiliki kreatifitas untuk mempromosikan bisnis mereka kepada target audiens yang dituju. Maka dari itu, peran fotografi dan videografi berpengaruh besar dalam mempromosikan sebuah bisnis agar dapat menarik minat target audiens dan terlihat lebih meyakinkan untuk dijual. Konsep fotografi yang diangkat yaitu fotografi makanan dan landscape, kemudian konsep videografi menggunakan teknik berupa B-Roll dan cinematic, hasil dari perancangan di unggah pada sosial media Instagram @ reginakopii yang memiliki tujuan untuk mempromosikan kafe Regina kemudian menggunakan jasa Instagram ads untuk memperluas promosi di sosial media. Metode perancangan ini menggunakan data primer dan data sekunder yang dalam pengumpulan datanya menggunakan metode kualitatif. Kesimpulan dari perancangan yaitu mendapatkan hasil visual berupa kumpulan foto - foto makanan dan 2 video yang mengusung tema profil kafe. Perancangan ini juga didukung oleh beberapa media pendukung seperti sosial media Instagram, t-shirt, masker, totebag, sticker, dan gantungan kunci akrilik.
\end{abstract}

Kata kunci: fotografi makanan, videografi $B$-Roll, videografi cinematic, sosial media, sebagai media promosi.

\begin{abstract}
With the increasing development of cafes in the East Java region, especially in Tulungagung Regency, competitors are increasing that it requires cafe business owners to have creativity in promoting their business to the intended target audience. Therefore, the role of photography and videography has an impact on the purpose of promoting a business so that it is more attractive to the target audience and looks more convincing to sell. The photography concept adopted is food and landscape photography, and this videography concept uses techniques in the form of B-Roll and cinematic, the results of which are uploaded to Instagram @ reginakopii social media aims to promote Regina cafe and then use Instagram advertising services to expand promotions on social media. This design method uses primary data and secondary data whose data collection uses qualitative methods. The conclusion of this design is to get visual results in the form of a collection of food photos and two videos that carry the cafe profile theme. This design is also supported by several supporting media such as Instagram social media, $t$-shirts, masks, tote bags, stickers, and acrylic key chains.
\end{abstract}

Keywords: food photography, B-Roll videography, cinematic videography, social media, as a promotional media.

\section{LATAR BELAKANG}

Di era modern saat ini, merebaknya sejumlah kafekafe di setiap daerah yang ada di Indonesia sudah menjadi pemandangan sehari-hari. Dapat dilihat dari banyaknya kafe yang mulai buka di tanah air bahkan dalam kota-kota kecil sudah mulai menjamur sejumlah orang atau individual yang membangun kafe-kafe seperti di kota-kota besar. Menggunakan beragam penyebutan, seperti kedai kopi, coffee shop, angkringan, bahkan kafe yang tersebar di seluruh daerah dalam berbagai golongan masyarakat terutama anak muda. Maraknya sebuah kafe tersebut juga disertai dengan tema dan tujuan tertentu. Sebagai contoh, beragam konsep unik kafe seperti colorful, vintage, minimalis, atau selalu dengan iringan musik, terjangkaunya harga, hingga sajian menu mereka dengan nuansa tradisional sampai modern dan menu-menu unik atau biasa disebut signature yang diracik khusus yang hanya ada di kafe tersebut, seakan menjadi suatu daya tarik tersendiri dalam mencari pelanggan. Hal-hal tersebut menunjukkan minat masyarakat yang tinggi akan keberadaan sebuah kafe (Lim, 2014).

Salah satunya adalah pemandangan menjamurnya kafe-kafe di Kabupaten Tulungagung yang merupakan salah satu kota kecil yang berada di Jawa Timur. Di Tulungagung ini, minat masyarakat pada kafe sudah mulai diperhitungkan bagi anak-anak muda yang juga merupakan target utama kebanyakan kafe di Tulungagung menurut survey dari penulis di Tulungagung, untuk lokasi kafe itu sendiri sudah tersebar diseluruh titik di Tulungagung. Dengan meningkatnya pembangunan kafe, para individual atau kelompok pemilik kafe-kafe tersebut memanfaatkan sosial media sebagai media promosi mereka untuk bersaing dengan kompetitor lain, pada umumnya mereka menggunakan desain bangunan kafe yang unik dan aesthetic yang disukai kebanyakan anak muda yang bisa digunakan untuk photoshoot pribadi maupun commercial , lalu pada sajian menu mereka yang dibuat kreatif dan beragam, kemudian satu hal penting dalam pemasaran kafe melalui sosial medianya yaitu dengan penggunaan konten visual yang menarik minat anak muda seperti fotografi dan videografi.

Fotografi dan videografi merupakan salah satu pendukung dari berkembangnya sebuah kafe disuatu daerah, selain sebagai teknik marketing, fotografi dan videografi merupakan alat komunikasi visual yang dapat menunjukkan atau memperkenalkan 
kepada masyarakat atau target market yang akan dituju, seperti apa, dimana, suasana, menu yang disajikan pada suatu kafe (Yusuf, 2017), dikarenakan pada era modern ini, saat seseorang akan mengunjungi sebuah kafe, mereka terlebih dahulu akan melihat di sosial media untuk mendapatkan informasi dan hal itu dapat membujuk atau membuat pelanggan berkeinginan mengunjungi kafe yang dituju (Setiadi, 2003).

Pada saat ini dikarenakan media promosi banyak menggunakan foto atau video, penulis menjabarkan jenis food photography cocok digunakan sebagai basis dari perancangan konten visual berupa foto menu pada sebuah kafe, dan jenis landscape photography sebagai basis dalam pemotretan lokasi dan suasana kafe tersebut. Penulis memilih food photography karena melihat masih banyak UMKM / UKM di Indonesia yang kurang memahami pentingnya food photography dan landscape photography dalam persaingan bisnis kafe mereka. Kemudian dapat dijadikan sebagai salah satu cara untuk mengekspresikan bakat minat secara kreatif dan mengarahkan pada bisnis dengan mengekspose hasil dari fotografi kita ke media sosial. Tidak hanya fotografi, videografi juga menjadi bagian penting sebagai media promosi, bahkan videografi dengan durasi yang singkat dapat menyampaikan iklan secara lebih detail sehingga menjadi lebih menarik bagi konsumen (Yuliadi, 2020)

Food photography sesuai dengan istilahnya, fotografi makanan ini menampilkan objek foto makanan atau minuman dalam beragam jenis, awalnya jenis foto makanan ini termasuk dalam stil life photography, yang kemudian berkembang guna sebagai kebutuhan komersial yang bertujuan menghasilkan foto makanan yang nampak lezat dan menarik dengan tujuan advertising untuk dijadikan bagian dari desain kemasan, atau sebagai visual penunjang dalam buku menu, poster, dan sosial medianya. Tetapi agar dapat menghasilkan food photography yang memuaskan ada teknik dan cara dalam memotret dengan pencahayaan yang sesuai. Industri kuliner, seperti produsen makanan, rumah produksi, periklanan, hotel, kafe, dan lainnya, food photography secara mutlak dibutuhkan (Humaniora, 2014). Kemudian jenis landscape photography, merupakan salah satu jenis fotografi yang sudah lama dikenal dalam bidang fotografi yang umumnya menampilkan bagian yang cukup luas dari suatu lokasi (Agnes, 2014), yang pada masa kini, teknik landscape tersebut banyak digunakan tidak hanya untuk pemotretan alam, tetapi digunakan sebagai advertising seperti pemotretan gedung, rumah, kafe, lapangan, dan lainlain.

Video adalah media audio visual yang menampilkan gambar dan suara. Pesan yang disajikan berupa fakta (kejadian, peristiwa penting, berita) maupun fiktif (seperti misalnya cerita), bisa bersifat informatif, edukatif maupun instruksional. Videografi merupakan suatu kegiatan merekam sebuah moment/kejadian yang dirangkum dalam sebuah sajian gambar dan suara, videografi termasuk dalam sarana media promosi untuk memperkenalkan sebuah brand secara lebih detail lagi, dengan adanya video, sebelum membeli

atau berkunjung ke sebuah tempat, masyarakat dapat melihat seperti apa bentuk, warna, ukuran dari sebuah produk, suasana, dan lain-lain agar dapat membandingkan ukurannya biasanya digunakan model sebagai referensi (Yuliadi, dkk, 2020)

Berdasarkan hal-hal tersebut, judul tugas akhir yaitu

"Perancangan Konten Visual Sebagai Media Promosi Kafe Regina Di Tulungagung" untuk memperkenalkan sebuah kafe baru kepada masyarakat sekitar di Tulungagung dinilai penting untuk meningkatkan usaha kafe Regina Tulungagung berbentuk yang fotografi dan videografi sebagai media promosi di sosial media mereka berupa instagram. Kafe "Regina Kopi" ini memiliki nama "Regina" yang berdiri sejak Oktober 2020, dengan pemilik usaha kafe bernama Albertus Leo Wicaksana yang merupakan mahasiswa lulusan Teknik Industri Universitas Atma Jaya. Kafe ini berdomisili di Kabupaten Tulungagung, alamat tepatnya berada di Jalan KH Hasyim Asyari No.67, Kauman, Kalangbret. Menu yang ditawarkan berupakan makanan berat seperti chicken katsu, spageti, rice bowl, kemudian berbagai macam snack yaitu french fries, onion fries, toast, dan masih banyak lainnya, kemudian berbagai macam minuman kopi dan tanpa kopi. Dikarenakan kafe "Regina" melakukan promosi dengan sosial media berupa instagram, maka diperlukan konten visual yang menarik agar dapat memperkenalkan kafe tersebut di masyarakat, sebab kafe

"Regina" merupakan salah satu kafe pertama yang dibangun tepatnya di area Kecamatan Kauman, Kabupaten Tulungagung dan menjual berbagai macam variant kopi organik (kopi yang proses penyeduhan menggunakan mesin kopi dan langsung jadi saat itu juga), memiliki harga yang sangat terjangkau bahkan lebih terjangkau daripada kompetitor lain yang bergerak dibidang yang sama menurut wawancara dengan pemilik kafe, lalu memiliki menu yang cukup bervariatif, maka dibutuhkan fotografi dan videografi dari menu dan lokasi untuk melengkapi Instagram dari kafe tersebut agar dapat menarik minat konsumen yang melihatnya.

\section{Metode Perancangan}

Dalam sebuah perancangan dibutuhkan beberapa metode dalam proses pengambilan data untuk menjadi pedoman utama perancangan. Metode perancangan yang digunakan dalam perancangan konten visual untuk kafe Regina terdapat dua macam data, diantaranya adalah data primer dan data sekunder. Metode yang digunakan untuk memperoleh data primer adalah melalui wawancara secara langsung pada pelanggan kafe Regina atau masyarakat sekitar Tulungagung, serta dengan melakukan riset lapangan dan mengumpulkan data-data visual. Sedangkan metode yang digunakan untuk memperoleh data sekunder adalah dengan studi literature melalui buku dan internet. Maka dari itu digunakan metode perancangan secara kualitatif untuk perancangan konten visual kafe Regina di Kabupaten Tulungagung berupa wawancara, observasi, dan dokumentasi. 


\section{Metode Pengumpulan Data}

Data yang digunakan dalam perancangan ini dikumpulkan secara kualitatif kepada informan objek perancangan yaitu pemilik kafe Regina dan pelanggan dari kafe Regina. Pengumpulan data dalam perancangan ini menggunakan pengumpulan data penelitian kualitatif didapatkan melalui beberapa cara, yaitu wawancara mendalam, observasi, dan dokumentasi (Prastowo; 2011: pp.212-230).

Wawancara adalah proses memperoleh keterangan untuk ujuan penelitian dengan cara tanya jawab sambil bertatap muka antara pewawancara dan informan yang terlibat dalam suatu kehidupan sosial. Wawancara mendalam dilakukan bersama informan dalam waktu tertentu secara bertahap di lokasi penelitian. Wawancara mendalam dilakukan secara tidak formal dan tidak sistematik sehingga data yang didapat bisa berupa data verbal dan non-verbal. Oleh karena itu, perlu adanya persiapan sebelum wawancara dilakukan seperti persiapan pertanyaan wawancara, persiapan pengetahuan yang cukup tentang hal yang ditanyakan, buku catatan ataupun tape recorder untuk memudahkan proses wawancara nantinya (Prastowo; 2011: pp.212-217). Wawancara dalam perancangan ini akan dilakukan langsung kepada pemilik usaha kafe dan target market, kemudian tujuan dari wawancara ini adalah untuk mendapatkan data tentang kompetitor dalam bersaing dan berpikir kreatif dalam memasarkan bisnis mereka di masyarakat dengan menggunakan sosial media.

Observasi adalah teknik pengumpulan data melalui pengamatan terhadap objek pengamatan dengan langsung hidup bersama, merasakan, serta berada dalam aktivitas kehidupan objek pengamatan. Kegiatan observasi memiliki tingkat akurasi data yang baik tetapi memakan waktu yang lama. Hal-hal yang dapat diperhatikan saat melakukan observasi adalah: pemahaman terhadap objek pengamatan; pencatatan data yang tidak mengganggu objek pengamatan; menjaga hubungan baik dengan objek pengamatan; serta durasi dan luas lingkup pengamatan yang dilakukan (Prastowo; 2011: pp.220-222).

Dalam perancangan ini akan dilakukan observasi pada sebuah kafe - kafe yang sudah cukup terkenal di Kabupaten Tulungagung. Observasi ini juga akan difokuskan kepada target market usia sekitar 15 tahun hingga 30 tahun. Tujuan dari dilakukannya observasi ini adalah mendapatkan data tentang perilaku masyarakat Tulungagung dalam melakukan kegiatan nongkrong di suatu kafe.

Dokumentasi merupakan kegiatan pengumpulan informasi yang didapat dari dokumen, yakni peninggalan tertulis, arsip-arsip, akata ijazah, rapor, peraturan perundangundangan, buku harian, surat pribadi, catatan biografi dan lain-lain yang memiliki keterkaitan dengan masalah yang diteliti. Dokumentasi pada dasarnya berupa rekaman yang bersifat tertulis atau film dan berisi peristiwa yang telah berlalu. Dokumentasi memungkinkan data yang didapat dari wawancara ataupun observasi menjadi lebih kredibel dengan bukti fisik yang telah dikumpulkan
(Prastowo; 2011: pp.226227). Dokumentasi yang akan dicatat dalam perancangan ini adalah dari hasil wawancara dan tinjauan lapangan dengan mencatat dan mendokumentasikan semua hal-hal yang penting agar mendapatkan data yang lebih akurat dan terjamin kebenarannya.

\section{Metode Konsep Perancangan}

Metode konsep yang digunakan dalam perancangan ini menggunakan metode konsep perencanaan kreatif. Konsep perencanaan kreatif merupakan konsep untuk menciptakan hal baru, dalam konteks ini adalah pesan. Pesan kreatif mencakup pesan secara visual dalam desain komunikasi visual (Sanyoto; 2006: pp.61-62). Dalam perencanaan konsep kreatif, terdapat beberapa komponen, yaitu;

Tujuan kreatif merupakan pengaruh atau pesan yang ingin ditanamkan pada target audience melalui produk atau iklan yang dirancang. Pengaruh dari tujuan kreatif dapat berupa pesan yang hendak disampaikan ataupun respon yang diinginkan terjadi pada target audience terhadap perancangan yang dibuat nantinya. Dalam perancangan Tugas Akhir ini akan digunakan tujuan kreatif produk rintisan yang berfokus pada tahap pengenalan dan pemahaman (awareness) (awareness and knowledge) dari perancangan yang dihasilkan (Sanyoto; 2006: pp.78-80).

Strategi kreatif adalah kebijakan-kebijakan yang dilakukan terhadap paduan kreatif (isi dan bentuk pesan), yang disusun berdasarkan target audience karena pada dasarnya target audience yang menentukan isi dan bentuk dari suatu pesan yang akan disampaikan. Titik berat dalam strategi kreatif adalah menentukan target audience kreatif dan menetapkan isi serta bentuk pesan yang akan disampaikan kepada target audience untuk memenuhi kebutuhan tujuan kreatif. Isi pesan merupakan ide-ide yang akan disampaikan kepada target audience, sedangkan bentuk pesan adalah visualiasi dari isi pesan yang dikemas agar menarik minat target audience (Sanyoto; 2006: pp.82-83).

Proses program kreatif merupakan realisasi dari strategi kreatif dengan melakukan pendataan kebutuhan elemen-elemen desain komunikasi visual dalam suatu perancangan kreatif. Pada bagian ini dilakukan pendataan ulang terhadap pokok-pokok kreatif dari pesan kreatif (isi dan badan pesan) yang digunakan sebagai dasar umum dalam perancangan. Hal -hal tersebut bisa berupa: headline (beberapa kemungkinan judul dan tema), konsep perancangan; script dari video, dan tone warna yang digunakan pada foto nantinya (Sanyoto; 2006: pp.105-106). Berikut sricpt dari masing-masing video yang akan dirancang:

\section{Video B-Roll OPENING}

Pengambilan video kafe Regina dari sebrang jalan disertai kendaraan yang sedang lewat.

Pengambilan gambar logo kafe Regina dengan close up. MIDDLE EARLY

Pengambilan video dengan menggunakan talent yang sedang berjalan masuk. 
Talent membuka pintu dan melihat dengan kagum.

Pengambilan gambar lokasi dalam kafe Regina.

Shot close up furniture di dalam kafe Regina seperti lampu, nomor meja. ENDING

Interaksi pelanggan bermain ekspresi seperti melihat hp, mengaduk minuman, makan, atau tersenyum menghadap kamera.

\section{Video Cinematic OPENING}

Pengambilan gambar pada furniture di dalam kafe seperti gelas, botol berisikan bahan pembuatan minuman untuk menunjukkan gelas/bahan yang digunakan.

Barista mengambil gelas.

\section{MIDDLE EARLY}

Biji kopi dituang ke mesin dengan 3 angle yang berbeda.

Dari depan sehingga terlihat setengah badan dari barista.

Dari dalam wadah kopi memperlihatkan kopi yang dituangkan ke dalam wadah.

Barista membuat kopi menggunakan mesin kopi dengan dramatis dikarenakan pergerakan kamera.

\section{ENDING}

Menaruh snack ke piring dari atas (dijatuhkan).

Dari sebelah kanan kiri masuk sepiring snack dan minuman seakan menyajikan untuk pelanggan.

Biaya kreatif merupakan segala biaya yang dikeluarkan dalam perencanaan dan perancangan yang dilakukan. Biaya kreatif menyangkut biaya produksi dan penggandaan produk yang dihasilkan seperti biaya cetak dan biaya-biaya lain yang dibutuhkan agar perancangan dapat selesai secara optimal (Sanyoto; 2006: p.107). Dalam perancangan konten visual ini biaya kreatif yang dimaksud adalah persewaan alat-alat seperti kamera dan lensa agar dapat menghasilkan hasil yang baik nantinya dan biaya untuk merchandise.

\section{Visualisasi Desain}

Visualisasi desain merupakan langkah untuk memberikan daya tarik pada suatu produk agar dapat memikat target audience. Dalam prosesnya, visualisasi desain memiliki beberapa tahapan konsep perancangan, yaitu: pra produksi, produksi, pasca produksi, dan final. Konsep perancangannya adalah media fotografi dan videografi yang merupakan konten visual untuk media promosi kafe Regina, dirancang dalam bentuk foto-foto yang akan di unggah di feeds Instagram dari kafe Regina dan video promosi menggunakan teknik-teknik dari fotografi dan videografi. Target audience dari perancangan ini adalah remaja sampai dewasa usia 15 tahun hingga 30 tahun. Untuk dapat mewujudkan perancangan konten visual yang dapat menjawab permasalahan, maka diperlukan berbagai strategi maupun konsep perancangan yang dapat memenuhi segala aspek yang diinginkan dan dapat bermanfaat bagi target audience perancangan. Konsep perancangan adalah tahapan yang sangat penting untuk dilakukan karena ditahap inilah akan ditentukan hasil dari perancangan. Konsep perancangan ini akan terdiri dari konsep pesan dan konsep visual.

Pada konsep pesan berdasarkan data dari analisis data yang didukung oleh teori-teori yang telah dijabarkan, maka akan ditarik konsep pesan yang akan menjadi acuan dalam perancangan ini. Konsep pesan merupakan sebuah isi yang akan disampaikan, yaitu mengenai bagaimana sebuah fotografi makanan dan videografi promosi dapat menarik minat masyarakat saat dijadikan sebagai media promosi.

Konsep visual pada perancangan konten visual ini akan menggunakan teknik fotografi makanan berupa zooming dan depth in field, lalu landscape dan portrait fotografi untuk mengambil ngambar suasana/lingkungan sekitar kafe, untuk hasil foto akan memiliki ukuran persegi yaitu 1:1 sesuai dengan ukuran standart feeds pada Instagram. lalu untuk teknik video adalah B-Roll dan yang masing-masing memiliki durasi 1 menit. Dalam perancangan konten visual ini setelah beberapa konten seperti foto makanan/suasana telah selesai, akan di unggah terleih dahulu pada feeds Instagram dari kafe Regina kemudian menyusul untuk video.

\section{Pra Produksi}

Dalam bagian ini akan dilakukan sebuah pengerjaan visual pada perancangan konten visual sebagai media promosi kafe Regina. Tahapan yang akan dilalui adalah melakukan sedikit branding pada buku menu kafe agar terlihat bagus di video, mencari talent sebagai media pendukung saat sesi foto suasana dan makanan, menyiapkan kamera dan lensa, properti untuk foto makanan, mempersiapkan alat pendukung untuk rekam video yaitu stabilizer/gimbal.

\section{Produksi}

Pada tahap ini akan dilakukan sesi foto dan video yang melibatkan beberapa talent di lokasi. Foto akan dilakukan sesuai dengan konsep yang telah dibuat pada tahap pra produksi.

\section{Pasca Produksi}

Hasil dari karya fotografi dan videografi tersebut akan masuk kedalam tahap pasca produksi atau proses editing yang menggunakan software di computer. Software editing yang akan digunakan adalah Adobe Lightroom untuk editing foto dalam menyempurnakan pencahayaan dan pewarnaan pada foto, kemudian aplikasi di smartphone bernama Phonto untuk menambahkan beberapa typography pada foto, dan Adobe Premiere Pro untuk editing video.

\section{Final}

Desain final adalah hasil akhir dari sebuah konten visual sebagai media promosi yang telah siap untuk diluncurkan, yang sudah melalui proses pemilihan foto, editing, color grading. Desain final dari perancangan konten visual ini berupa foto - foto berukuran 1:1 yang akan di unggah pada Instagram kafe Regina untuk media promosi. 


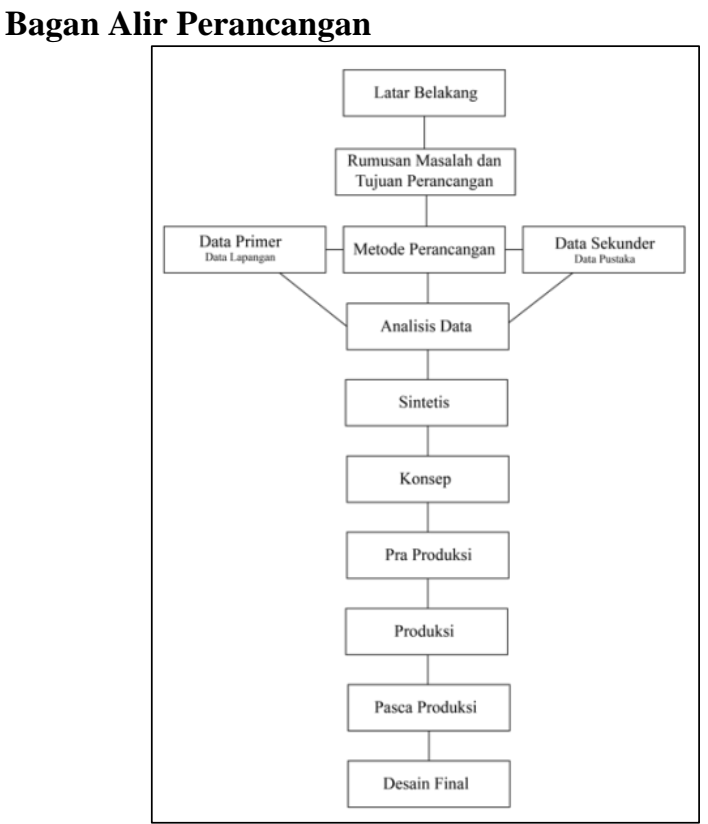

Gambar 1. Bagan Alir Perancangan

\section{Analisis Data Wawancara}

Dari data yang didapat pada proses pengumpulan data, sosial media merupakan salah satu media promosi yang memiliki nilai yang cukup tinggi pada masa kini untuk mempromosikan suatu usaha. Dengan menggunakan konten visual yang baik juga merupakan hal penting saat ingin melakukan promosi pada sosial media, konten visual yang digunakan berupa fotografi dan videografi, kedua hal tersebut sangat mendukung dalam memasarkan atau memperkenalkan sebuah brand, produk, atau bisnis ke sosial media. Begitu juga dengan para narasumber yang rata - rata mereka menggunakan sosial media Instagram untuk mengetahui apabila adanya tempat baru seperti kafe / coffe shop, dari wawancara yang telah dilakukan, mereka lebih tertarik dan yakin pada brand / produk yang di jual kepada akun Instagram yang memiliki feeds yang rapi dan bagus / aesthetic yang mana menggunakan feeds Instagram yang rapi perlu digunakan adanya fotografi yang baik, karena berdasarkan survey hal seperti itu dapat lebih meningkatkan ketertarikan pelanggan baru.

Selanjutnya untuk pemilihan tone warna yang tepat seperti warna yang cerah atau menggunakan high exposure pada fotografi dan videografi mempengaruhi hasil dari konten visual, untuk makanan lebih diperlukan tone warna yang cerah dan hangat supaya tidak merubah warna asli dari makanan tersebut. Narasumber perempuan lebih memilih lokasi yang memiliki desain aesthetic dan lebih memperhatikan kualitas feeds dari akun Instagram dari usaha kafe / coffe shop tersebut sedangkan narasumber laki - laki lebih memilih untuk mencari lokasi yang nyaman. Melalui data yang diperoleh, telah ditetapkan konsep yang digunakan untuk perancangan konten visual kafe Regina sebagai media promosi yaitu berupa foto - foto makanan / minuman dari menu, lokasi / suasana kafe, dan video promosi berupa video
B-Roll proses pembuatan minuman dan video profil yang nantinya akan di unggah oleh pemilik usaha pada akun Instagram kafe Regina.

Dari data yang telah dianalisis, dilakukan sintesis konsep untuk menyusun perancangan konten visual sebagai media promosi kafe Regina di Kabupaten Tulungagung. Pada konten visual ini akan berfokus pada visualisasi foto foto menu makanan, minuman, dan suasana yang ada pada kafe tersebut. Untuk konsep foto suasana akan berupa foto saat barista membuat makanan atau minuman, foto interaksi para pelanggan kepada teman nongkrong mereka, juga terdapat foto desain interior pada kafe tersebut. Kemudian pada konten visual berupa videografi, yang pertama akan berfokus pada saat pembuatan 1 atau 2 jenis menu favorit kafe Regina yang menggunakan konsep B-Roll, dan video kedua akan berkonsep video profil yang menampilkan desain interior dan suasana kafe. Untuk mendukung perumusan konsep perancangan, dilakukan perumusan terhadap beberapa tahapan yaitu tujuan kreatif, strategi kreatif, program kreatif, dan biaya kreatif yang akan dijelaskan pada bagian berikut:

Tujuan kreatif adalah pesan yang ingin ditanamkan pada target audience melalui konten visual yang dirancang sehingga didapatkan respon yang sesuai dari pesan yang disampaikan. Tujuan kreatif dari perancangan konten visual sebagai media promosi kafe Regina di Kabupaten Tulungagung ini adalah fotografi makanan / produk nantinya sudah pasti akan mewakili sebuah brand produk / kafe. Terlebih didukung kualitas fotografi yang baik, calon konsumen akan semakin yakin dengan apa yang ditawarkan oleh suatu kafe atau brand tersebut. Jika calon konsumen sudah merasa yakin dengan sebuah produk / kafe, peluang mereka untuk melakukan pembelian / kunjungan sangat besar. Kemudian tujuan dirancang media promosi berbasis konten visual yang nantinya akan dipasarkan secara online agar dapat menjangkau konsumen di lokasi yang dituju atau mampu menjangkau pasar yang lebih luas lagi. Metode pemasaran online sangat digemari saat ini karena kemudahan dan kepraktisannya hanya dengan menggunakan smartphone ataupun komputer dengan jaringan internet, maka kita mampu menjangkau target audience yang dituju atau semua konsumen dimanapun mereka berada.

Strategi kreatif merupakan kebijakan-kebijakan yang dilakukan terhadap paduan kreatif (isi dan bentuk pesan). Paduan kreatif disusun berdasarkan target audience agar tujuan kreatif bisa disampaikan secara maksimal. Dalam perancangan ini, target audience yang diharapkan adalah orang-orang di wilayah Kabupaten Tulungagung dengan profesi sebagai pelajar, mahasiswa, dan pekerja berusia 15 hingga 30 tahun, laki-laki dan perempuan, memiliki gaya hidup yang menyukai nongkrong di kafe / coffe shop, eating out, atau melakukan photoshoot untuk trend kafe baru di suatu daerah. Dapat dibuat paduan kreatif sebagai bagian dari strategi kreatif perancangan ini. Paduan kreatif terdiri dari isi dan bentuk pesan. Isi pesan merupakan ide-ide yang akan disampaikan kepada target audience. Sedangkan bentuk pesan adalah visualisasi isi pesan yang dikemas agar menarik minat 
Dalam perancangan ini, isi pesan yang akan disampaikan adalah memperkenalkan sebuah kafe baru yang ada di Kabupaten Tulungagung melalui sosial media dari akun Instagram @reginakopii menggunakan konten visual berupa video yang pertama memiliki konsep proses pembuatan salah satu minuman favorit, yang kedua video profil dengan teknik cinematic yang memperlihatkan desain interior kafe Regina dan interaksi pelanggan di lokasi, kemudian fotografi berjenis food photography dan landscape photography suasana dari kafe yang nantinya akan menjadi referensi untuk masyarakat sekitarnya sebelum memutuskan untuk mengunjungi kafe Regina. Dalam penyampaian pesan tersebut dibutuhkan suatu cara agar setiap orang yang melihat bisa memahami pesan pemasaran tersebut. Oleh karena itu, dikumpulkan pengalaman - pengalaman dari 3 wirausahawan yang cukup lama berkecimpung di dunia kafe yang mengedepankan sosial media mereka untuk alat promosi dan narasumber yang sesuai dengan target market yaitu pelajar, mahasiswa, pekerja dengan usia 15 hingga 30 tahun yang berdomisili di Tulungagung. Pengalaman - pengalaman tersebut akan dijadikan referensi untuk perancangan konten visual sebagai media promosi untuk akun sosial media kafe Regina. Setelah konten selesai, kemudian akan dipromosikan lebih luas menggunakan Instagram Ads dan endorse yang bertema review makanan / kafe pada akun Instagram kuliner atau akun yang berisikan info - info tentang Tulungagung yang cukup terkenal seperti @kacamatatulungagung dan @ njajan.tulungagung.

Program kreatif merupakan realisasi dari strategi kreatif yang telah dibuat. Data tersebut meliputi kebutuhan elemen-elemen Desain Komunikasi Visual yang dibutuhkan dalam perancangan yang akan dijelaskan sebagai berikut: Instagram feeds, dikarenakan penggunaan sosial media Instagram sebagai media promosi online kafe Regina, maka memerlukan konten visual yang diletakkan pada Instagram feeds, nantinya feeds dari Instagram kafe Regina akan berisi 2 konten berupa foto dan video yang meliputi foto - foto makanan dan minuman sesuai menu dari kafe, foto - foto suasana, lokasi dan interaksi pengunjung, kemudian di sela - sela feeds yang berisikan foto, akan di unggah 2 video BRoll dan yang telah melalui tahap editing dan di tata rapi dengan tone warna / color grading yang sama. Perancangan Instagram feeds berupa fotografi dimulai dari beberapa konsep yaitu sebagai berikut; pada konten visual berupa fotografi ini berjenis food photography dan landscape photography dengan menggunakan visualisasi warna high exposure. High exposure dipilih karena mampu meningkatkan warna dari makanan / minuman dan suasana yang menjadi objek foto agar terlihat lebih menarik dan cerah, high exposure juga memiliki keunggulan dalam menyetarakan mood cerah dari foto yang diambil di beberapa tempat yang berbeda. Tone warna yang dipilih yaitu orange highlight dan yellow shadows yang menjadi kontras komplementer warna. Kemudian pada konten visual berupa videografi ini akan ada 2 jenis video yaitu video BRoll dan Cinematic. Pada video memiliki konsep seperti video profil sedangkan video B-Roll akan menunjukkan aksi barista dalam pembuatan kopi / minuman lainnya. Pada video akan menggunakan teknik video long dan pada video B-Roll akan menggunakan teknik close up, medium close up dengan pergerakan kamera follow. Perancangan kedua video berikut ini diawali dengan pembuatan script.

\section{Pra Produksi}

Tahap pra produksi adalah tahap pencarian data awal oleh penulis yang menjadi pedoman melakukan tahap produksi, data yang didapat kemudian dijadikan bahan untuk menentukan alur dari konten visual sebagai media promosi yang akan dibuat. Sebelum masuk ketahap produksi, dikarenakan terdapat 2 jenis konten visual, yang perlu dipersiapkan dahulu untuk fotografi adalah tema, equipment, property dan pencarian talent. Kemudian untuk videografi adalah konsep perancangan.

\section{Fotografi}

\section{Tema}

Menurut Kamus Besar Bahasa Indonesia (KBBI) tema adalah ide pokok atau dasar cerita. Tema dari fotografi ini adalah periklanan yang digunakan sebagai media promosi melalui sosial media dengan teknik fotografi yaitu food photography dan landscape fotografi. Fotografi ini dibuat untuk memberi masyarakat/ audiens suatu referensi pada tempat baru yang ada di Tulungagung yaiut café Regina melalui fotografi yang menampilkan menu apa saja yang ada pada café ini dan seperti apa lokasi / suasana café.

\section{Equipment}

Equipment merupakan salah satu hal yang penting dalam menghasilkan sebuah gambar, penggunaan equipment yang semakin bagus maka akan mendukung proses pengambilan gambar semakin baik. Ada beberapa equipment yang digunakan dalam perancangan konten visual sebagai media promosi kafe Regina, antara lain Sony a6000, Lensa Fix Sony 24-70mm, Sandisk Extreme Pro 32 GB, Reflector, Softbox 60x90 cm, dan properti foto makanan. Kelengkapan equipment tersebut digunakan untuk mendukung penataan lighting pada lokasi pengambilan gambar.

\section{Videografi}

Berdasarkan survey yang dilakukan, penulis memperoleh gambaran konsep konten visual videografi yang akan divisualisasikan dalam 2 jenis video, yang pertama jenis B-Roll dalam durasi 1.30 menit dan cinematic dalam durasi 1 menit, dengan menekankan bagian proses pembuatan salah satu minuman best seller kafe Regina yaitu kopi dan suasana kafe. Sehingga pada tahap pra produksi videografi ini memerlukan adanya konsep perancangan agar memudahkan penentuan alur saat take video. Berikut susunan konsep perancangan masing-masing video; 1 . Video B-Roll

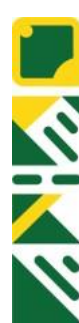


Tabel 1. Konsep Perancangan B-Roll

\begin{tabular}{|c|c|c|c|c|c|}
\hline No & Topik & Teknik & Adegan & Durasi & Musik \\
\hline \multirow[t]{2}{*}{1.} & \multirow[t]{2}{*}{ Opening } & \multirow{2}{*}{$\begin{array}{l}\text { *Sudut take video; } \\
\text { close up dan medium } \\
\text { close up dengan eye } \\
\text { level view } \\
\text { Effect: Slow Mo }\end{array}$} & $\begin{array}{l}\text { logo besar regina di } \\
\text { dalam kafe }\end{array}$ & \multirow[t]{2}{*}{7 detik } & \multirow{2}{*}{$\begin{array}{l}\text { Opening } \\
\text { Beat Slow } \\
\text { Music }\end{array}$} \\
\hline & & & $\begin{array}{l}\text { botol-botol sirup } \\
\text { bahan pembuatan } \\
\text { minuman, kaleng } \\
\text { kopi. }\end{array}$ & & \\
\hline \multirow[t]{3}{*}{2.} & \multirow[t]{3}{*}{ Middle } & $\begin{array}{l}\text { *Sudut take video; } \\
\text { medium close up } \\
\text { dengan eye level } \\
\text { view } \\
\text { *Teknik gerak } \\
\text { kamera: follow }\end{array}$ & $\begin{array}{l}\text { Objek 1 : Barista } \\
\text { mengambil } \\
\text { portafilter }\end{array}$ & 4 detik & \multirow[t]{3}{*}{$\begin{array}{l}\text { Beat } \\
\text { Music + } \\
\text { Soundtrack } \\
\text { (suara alami } \\
\text { Dari perge- } \\
\text { seran benda } \\
\text { pada video) }\end{array}$} \\
\hline & & $\begin{array}{l}\text { *Sudut take video; } \\
\text { medium close up dan } \\
\text { close up dengan eye } \\
\text { level view, frog eye } \\
\text { view, high angle } \\
\text { *Teknik gerak } \\
\text { kamera: follow, tilt }\end{array}$ & $\begin{array}{l}\text { Objek } 2 \text { : barista } \\
\text { mengambil biji } \\
\text { kopi dan menuang } \\
\text { ke mesin } \\
\text { (+ slow mo effect \& } \\
\text { suara biji kopi } \\
\text { dituang) }\end{array}$ & 9 detik & \\
\hline & & $\begin{array}{l}\text { *Sudut take video; } \\
\text { medium close up dan } \\
\text { close up dengan eye } \\
\text { level view, high } \\
\text { angle } \\
\text { *Teknik gerak } \\
\text { kamera: follow }\end{array}$ & $\begin{array}{l}\text { Objek } 3 \text { : Barista } \\
\text { memegang } \\
\text { portafilter dan } \\
\text { menunggu bubuk } \\
\text { kopi keluar dari } \\
\text { mesin kopi }\end{array}$ & 5 detik & \\
\hline
\end{tabular}




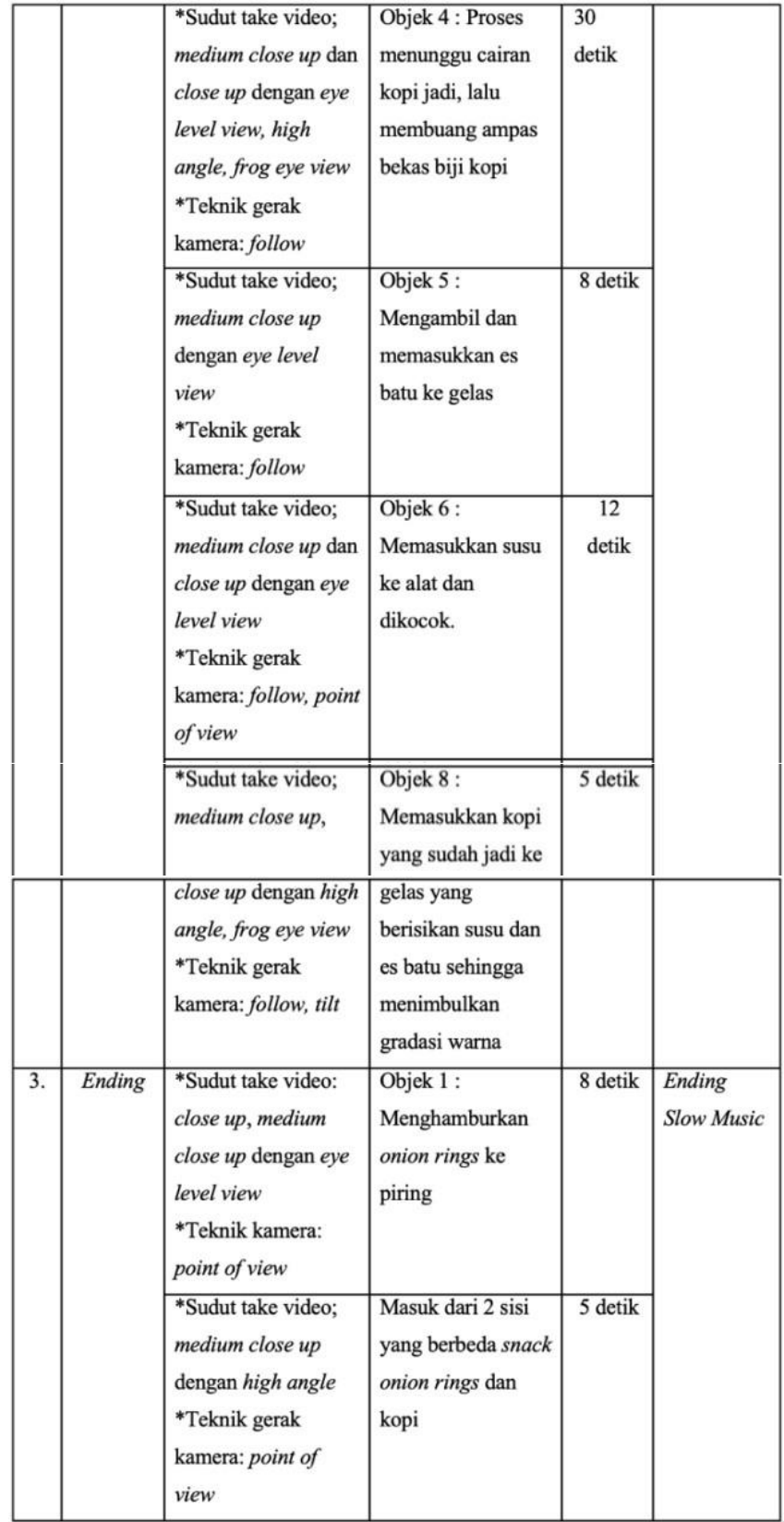

Tabel 2. Konsep Perancangan Cinematic
2. Video Cinematic

\begin{tabular}{|c|c|c|c|c|c|}
\hline No & Topik & Teknik & Adegan & Durasi & Musik \\
\hline 1. & Opening & $\begin{array}{l}\text { Frame: Long } \\
\text { shot } \\
\text { Gerak kamera: } \\
\text { Dolly }\end{array}$ & $\begin{array}{l}\text { Shot logo dalam kafe } \\
\text { regina (logo bulat hitam } \\
\text { besar) } \\
\text { Shot logo depan kafe } \\
\text { regina (logo tulisan } \\
\text { "regina diatas pintu } \\
\text { masuk" }\end{array}$ & 7 detik & \multirow{6}{*}{$\begin{array}{c}\text { Cinematic } \\
\text { Song } \\
\text { (tema } \\
\text { lagunya } \\
\text { alam) }\end{array}$} \\
\hline \multirow[t]{5}{*}{2.} & \multirow[t]{5}{*}{ Middle } & $\begin{array}{l}\text { Frame: Long } \\
\text { Shot } \\
\text { Gerak } \\
\text { Kamera: Dolly }\end{array}$ & $\begin{array}{l}\text { Shot tampak depan } \\
\text { bagian luar kafe regina }\end{array}$ & 7 detik & \\
\hline & & $\begin{array}{l}\text { Close Up }+ \\
\text { Slow mo } \\
\text { Medium Close } \\
\text { Up }\end{array}$ & $\begin{array}{l}\text { Shot lampu dalam regina } \\
\text { dari mati ke nyala }\end{array}$ & 5 detik & \\
\hline & & $\begin{array}{l}\text { Frame: Long } \\
\text { Shot }\end{array}$ & $\begin{array}{l}1 \text { orang talent masuk } \\
\text { kafe di shot dari } \\
\text { belakang, } \\
\text { mengelihatankan pintu } \\
\text { masuk kafe regina }\end{array}$ & $\begin{array}{c}10 \\
\text { detik }\end{array}$ & \\
\hline & & Long Shot & $\begin{array}{l}\text { Shot dari depan, talent } \\
\text { masuk sambil membuat } \\
\text { ekspresi kagum }\end{array}$ & 5 detik & \\
\hline & & $\begin{array}{l}\text { Medium Close } \\
\text { Up }\end{array}$ & $\begin{array}{l}\text { Talent sedang duduk di } \\
\text { dalam kafe (sambil } \\
\text { bermain ekspresi seperti } \\
\text { tersenyum sambil } \\
\text { melihat ke arah }\end{array}$ & $\begin{array}{c}10 \\
\text { detik }\end{array}$ & \\
\hline & & & $\begin{array}{l}\text { hp/makanan/keluar } \\
\text { jendela) }\end{array}$ & & \\
\hline & & $\begin{array}{l}\text { Long shot } \\
\text { Teknik shot; } \\
\text { panning }\end{array}$ & $\begin{array}{l}\text { Shot kafe regina tampak } \\
\text { depan (ada kendaraan2 } \\
\text { lewat) }\end{array}$ & 5 detik & \\
\hline 3. & Ending & $\begin{array}{l}\text { Medium Close } \\
\text { Up }\end{array}$ & $\begin{array}{l}\text { Shot logo depan kafe } \\
\text { regina (logo regina arah } \\
\text { ke jalan bentuk bulat, } \\
\text { posisi menyamping) }\end{array}$ & 5 detik & \\
\hline
\end{tabular}

\section{Produksi}

\section{Fotografi}

Pada tahap produksi ini penulis melakukan sesi foto di kafe Regina yang meliputi pengambilan foto makanan/minuman dan suasana kafe regina yang menyertakan interaksi barista dan pengunjung kafe. Sesi foto ini dilakukan selama 2 hari di $\quad$ kafe Regina yang berada di Kabupaten Tulungagung, pada hari pertama 1 Juli 2021 dimulai pukul 08.00 sampai pukul 15.00 dan hari kedua 4 Juli 2021 mulai pukul $09.00-13.00$. Sesi foto ini dimulai dengan penataan meja sebagai tempat meletakkan minuman/makanan, penataan properti pendukung foto, dan mencari lokasi dengan sinar matahari yang lebih banyak. Pada sesi foto makanan dan minuman menggunakan alat bantu fotografi yaitu reflector, kamera sony A6000 dengan lensa fix dan penggunaan ISO pada pengambilan gambar ini dibatasi hanya di angka ISO 200 -

320 untuk lokasi outdoor yang terkena banyak sinar matahari supaya tidak over exposure pada hasil foto dan ISO 500 untuk

sesi foto kopi yang berada di dalam ruangan agar menjaga supaya cahaya yang dihasilkan pada foto tetap senada lalu 
memiliki kualitas yang baik dan tajam sehingga meminimalisir noise pada foto. 2. Videografi

Pada tahap produksi konten visual videografi ini, penulis melakukan shooting video pada tanggal 6 Juli 2021 mulai pukul 09.00 hingga 17.00 yang berlokasi di kafe Regina Kabupaten Tulungagung, jenis video yang direncanakan adalah B-Roll dan cinematic, kedua jenis video ini membutuhkan talent berupa barista sebagai pengolah kopi pada video B-Roll dan 1 talent perempuan sebagai media pendukung video cinematic agar terdapat suatu interaksi dalam video tersebut. Kemudian isi dari laporan tugas akhir pada tahap produksi ini meliputi penjelasan scene pada masing-masing video sesuai dengan konsep perancangan yang telah dibuat. Penjelasan scene tiap video berisikan keterangan tentang kegiatan yang sedang dilakukan atau hal apa yang sedang terjadi, scene - scene pada masing- masing video di screenshot untuk menunjukkan scene yang paling utama pada tiap video.

\section{Pasca Produksi}

Setelah semua tahap produksi sudah dilewati yaitu pengambilan foto dan video dirasa sudah lengkap, barulah masuk pada tahap pasca produksi, yaitu proses editing pada foto dan video sebelum diuplooud pada sosial media Instagram kafe Regina, penjelasan tentang editing foto dan video adalah sebagai berikut;

\section{Fotografi}

Pada tahap editing foto ini menggunakan software Adobe Lightroom pada handphone, foto - foto yang telah dipilih melalui beberapa proses antara lain: cropping, straighten, color grading, contrast/brightness, curve, dan perbaikan pada tekstur foto apalagi kurang tajam/sebaliknya. Pada proses cropping, foto dipotong sesuai ukuran feeds Instagram sesuai acuan awal yaitu $4: 5$ dengan bantuan Rule of Thirds supaya komposisi foto seimbang, kemudian straighten adalah pembetulan rotate foto, seringkali saat memotret tidak sadar bahwa kamera tidak sejajar atau sedikit miring sehingga kesalahan tersebut bisa diperbaiki menggunakan straighten. Selanjutnya masuk pada fitur color grading agar menghasilkan tone warna yang sesuai, dengan bantuan contrast dan brightness dapat membuat foto ingin lebih terang atau lebih gelap, bisa juga menggunakan curve agar proses pengubahan kecerahan lebih presisi saat mengatur area highlight, shadow dan midtone pada foto, sedangkan untuk melakukan perbaikan tekstur pada foto dan warnanya supaya terlihat tajam dan tegas menggunakan fitur texture, clarity, dan dehaze pada Adobe Lightroom.
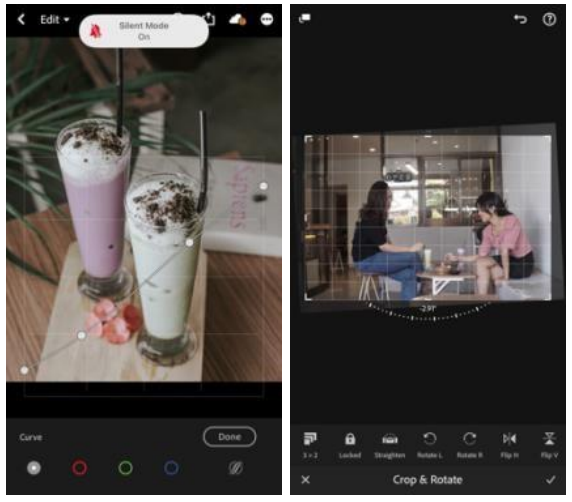

Gambar 2. Proses Editing Foto
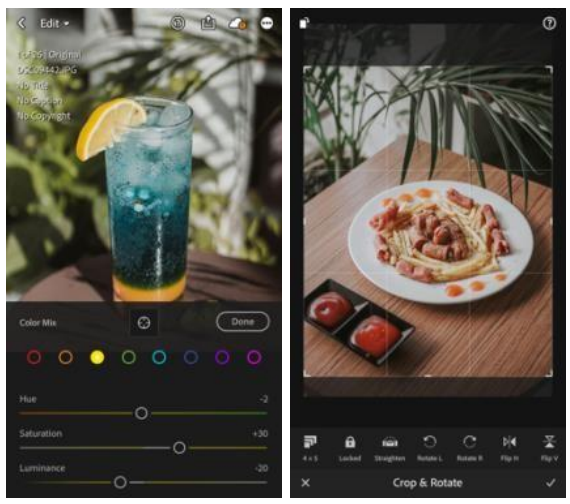

Gambar 3. Proses Editing Foto

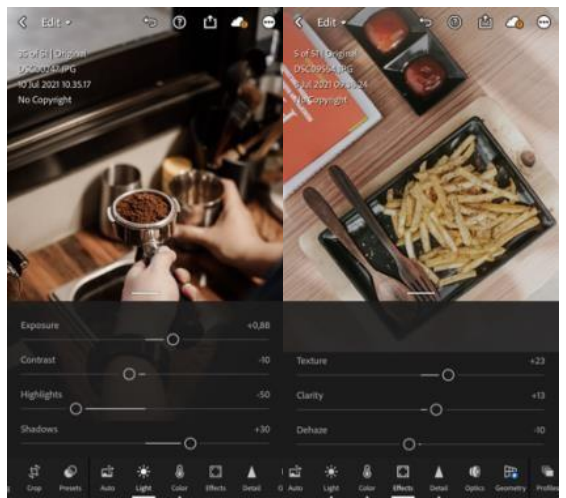

Gambar 4. Proses Editing Foto

\section{Videografi}

Dalam proses editing video ini penulis menggunakan software Davinci Resolve untuk video B-Roll dan software Adobe Premiere Pro untuk video cinematic, kedua software ini dipilih agar memudahkan penulis untuk editing video dan mendapatkan hasil akhir yang maksimal. Hal pertama yang dilakukan saat proses edit berlangsung adalah memasukan video yang sudah di sortir sesuai dengan alur yang ada pada konsep perancangan, kemudian melakukan proses cutting pada setiap - video yang akan dipakai beberapa scene tertentu saja, penambahan transisi dari video satu ke video lain agar perpindahan scene tidak terlalu kaku, tetapi untuk 
cinematic video tidak memerlukan terlalu banyak transisi karena jenis cinematic pada umumnya selalu menggunakan yang cenderung patah - patah daripada menggunakan transisi. Kemudian untuk mengatur durasi setiap footage, mau di percepat atau dibuat slow motion, kemudian salah satu yang terpenting adalah backsound, dengan menggunakan backsound sebagai media pendukung membuat video menjadi lebih dramatis dan mudah dipahami temanya, seperti tema B-Roll Coffe Shop akan lebih menggunakan backsound upbeat yang bertempo supaya dapat menyesuaikan dengan footage yang dihasilkan, lalu cinematic menggunakan backsound yang calm atau sedikit upbeat tetapi instrumental, dan yang terakhir yaitu color grading pada video, video yang penulis hasilkan menggunakan kamera Sony A6300 memiliki warna asli yang warm, sedikit pucat dan memiliki tone kebiruan, sehingga diperlukan sedikit color grading pada hasil akhir nanti supaya memiliki tone warna yang sesuai dengan suasana di kafenya. Color grading yang digunakan pada kedua video kafe regina ini orange and teal yang tipis dikarenakan warna asli hasil dari pengambilan video sudah cukup bagus. Setelah selesai Langkah selanjutnya adalah render dengan kualitas Youtube $4 \mathrm{k}$ supaya video yang dihasilkan tetap jernih dan tajam sesuai kualitas awal.

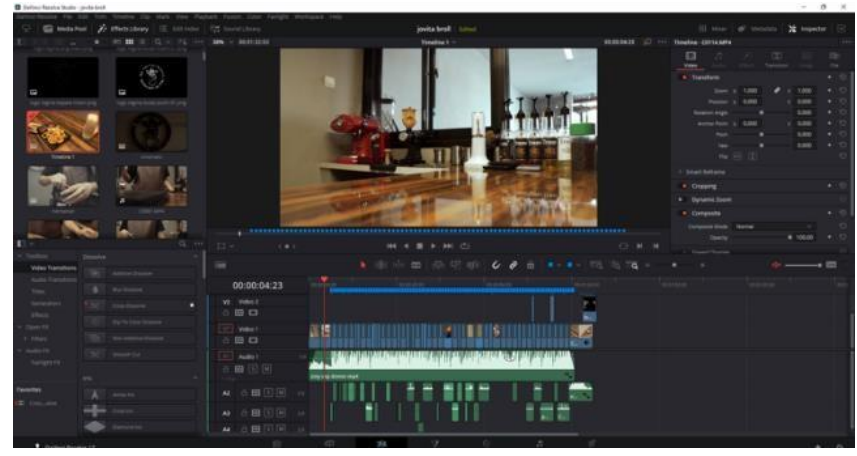

Gambar 5. Proses Editing Video

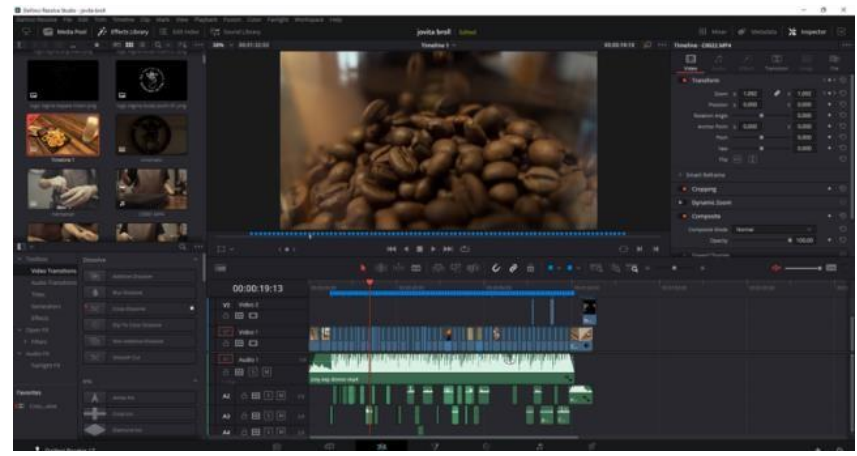

Gambar 6. Proses Editing Video

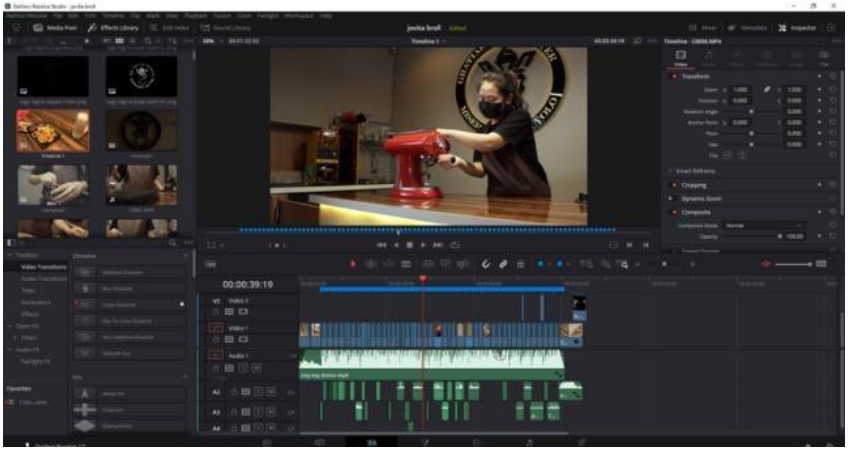

Gambar 7. Proses Editing Video

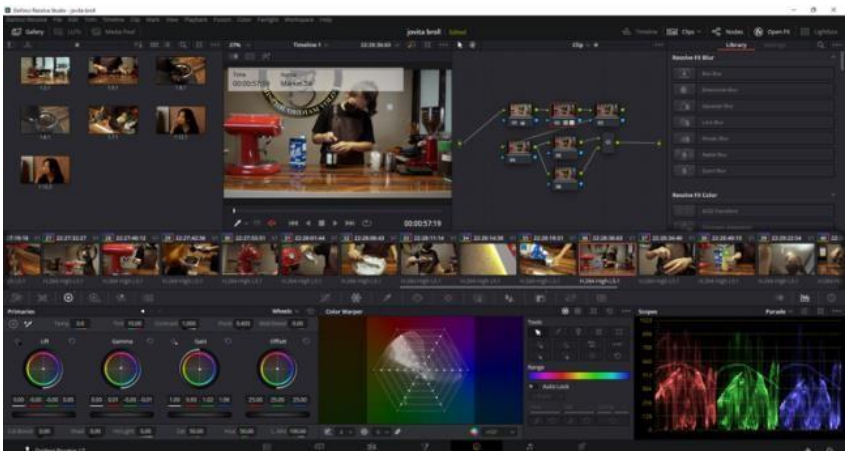

Gambar 8. Proses Editing Video

Final Tabel 3. Hasil Karya Foto

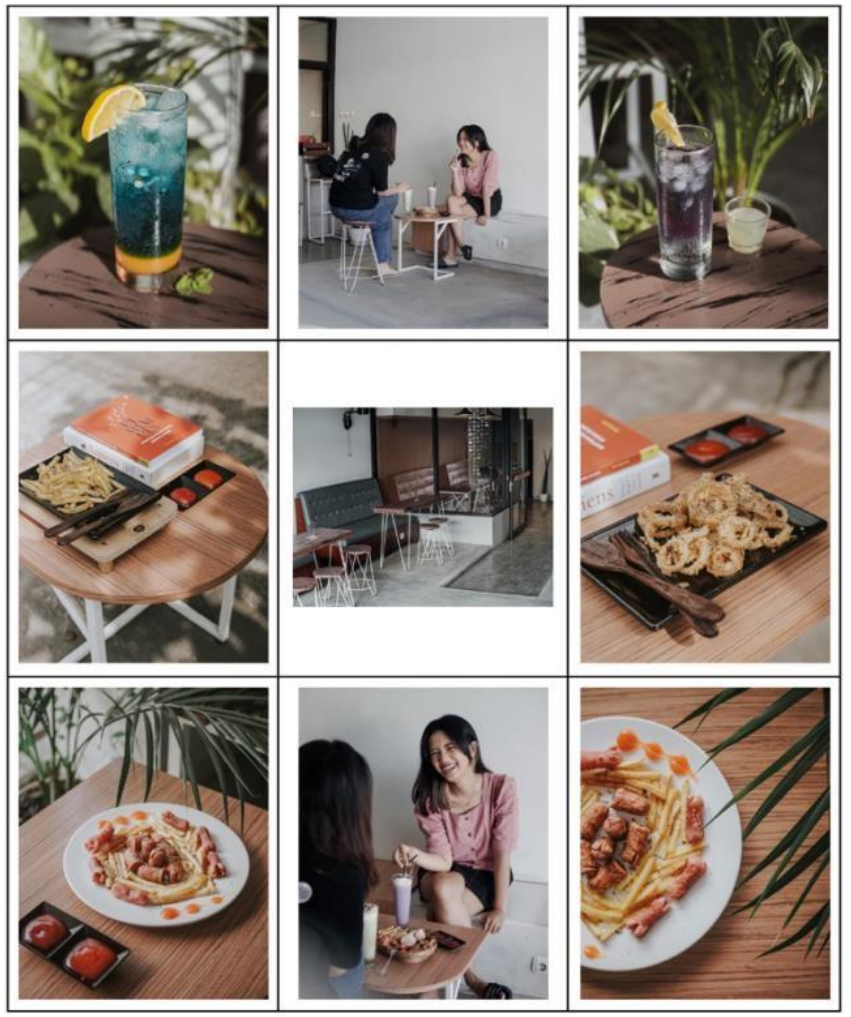



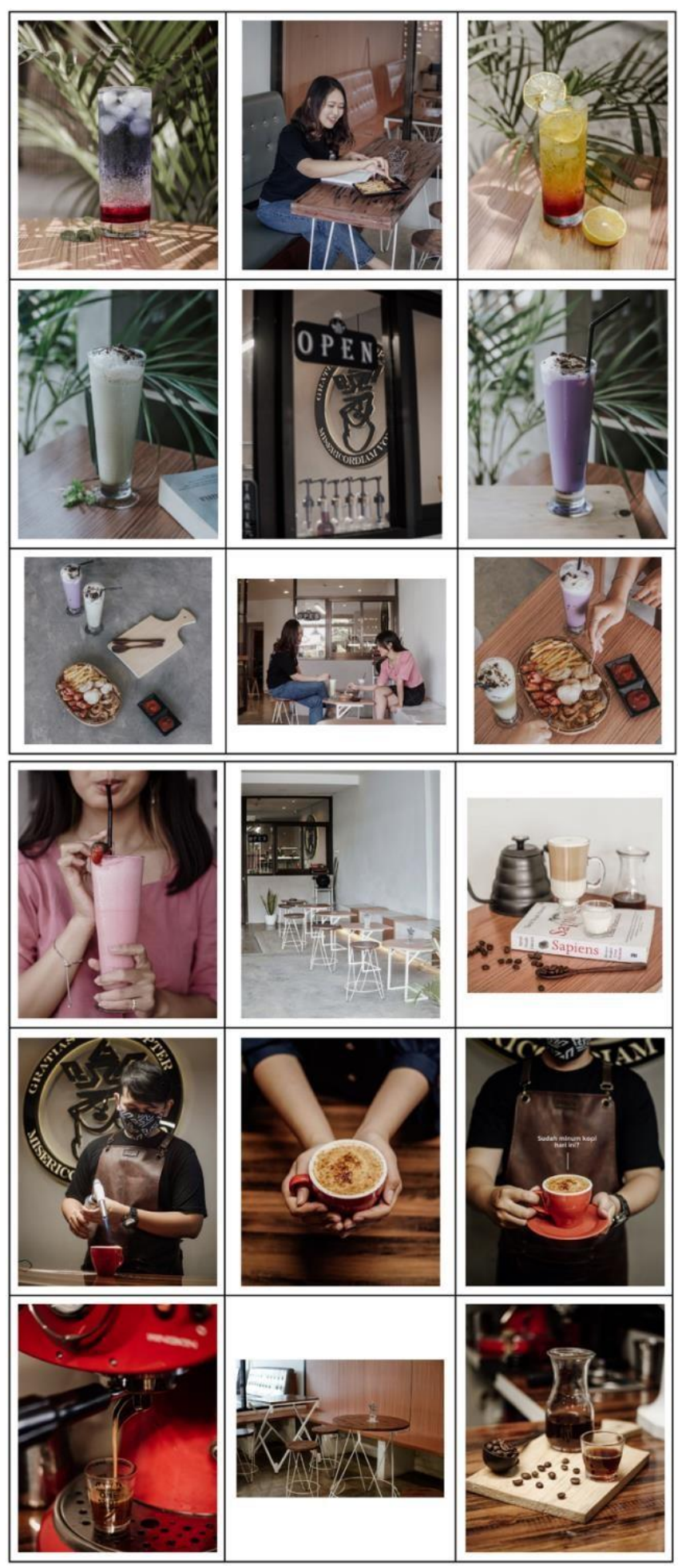

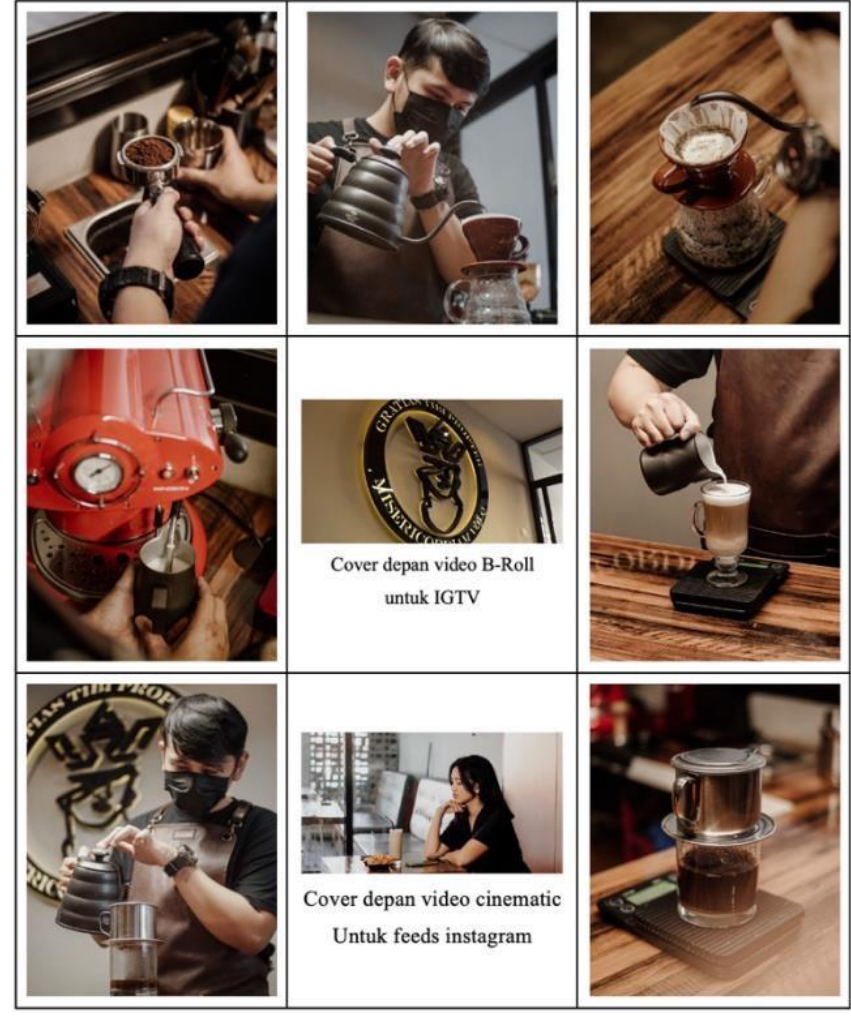

Tabel 4. Cuplikan Scene Hasil Karya Videografi B-Roll

\begin{tabular}{|c|c|c|c|}
\hline $\begin{array}{l}\text { Tangkapan } \\
\text { Layar }\end{array}$ & $\begin{array}{c}\text { Keterangan } \\
\text { Adegan }\end{array}$ & $\begin{array}{c}\text { Ukuran dan } \\
\text { Sudut } \\
\text { Pengambilan } \\
\text { Gambar } \\
\end{array}$ & $\begin{array}{c}\text { Gerak } \\
\text { Kamera }\end{array}$ \\
\hline & $\begin{array}{l}\text { Opening video, shot } \\
\text { logo dalam kafe }\end{array}$ & $\begin{array}{l}\text { Long shot } \\
\text { Frog eye } \\
\text { view }\end{array}$ & Pan Left \\
\hline & $\begin{array}{l}\text { Opening video meja } \\
\text { kasir dan barista } \\
\text { membuat kopi }\end{array}$ & $\begin{array}{l}\text { Long shot } \\
\text { Eye level } \\
\text { view }\end{array}$ & Dolly out \\
\hline & $\begin{array}{l}\text { Barista mengambil } \\
\quad \text { portafilter }\end{array}$ & $\begin{array}{c}\text { Medium close } \\
\text { up } \\
\text { Eye level } \\
\text { view }\end{array}$ & Follow \\
\hline & $\begin{array}{c}\text { Barista mengambil } \\
\text { biji kopi dari kaleng }\end{array}$ & $\begin{array}{c}\text { Medium } \\
\text { Close Up } \\
\text { Bird Eye } \\
\quad \text { View }\end{array}$ & Follow \\
\hline
\end{tabular}




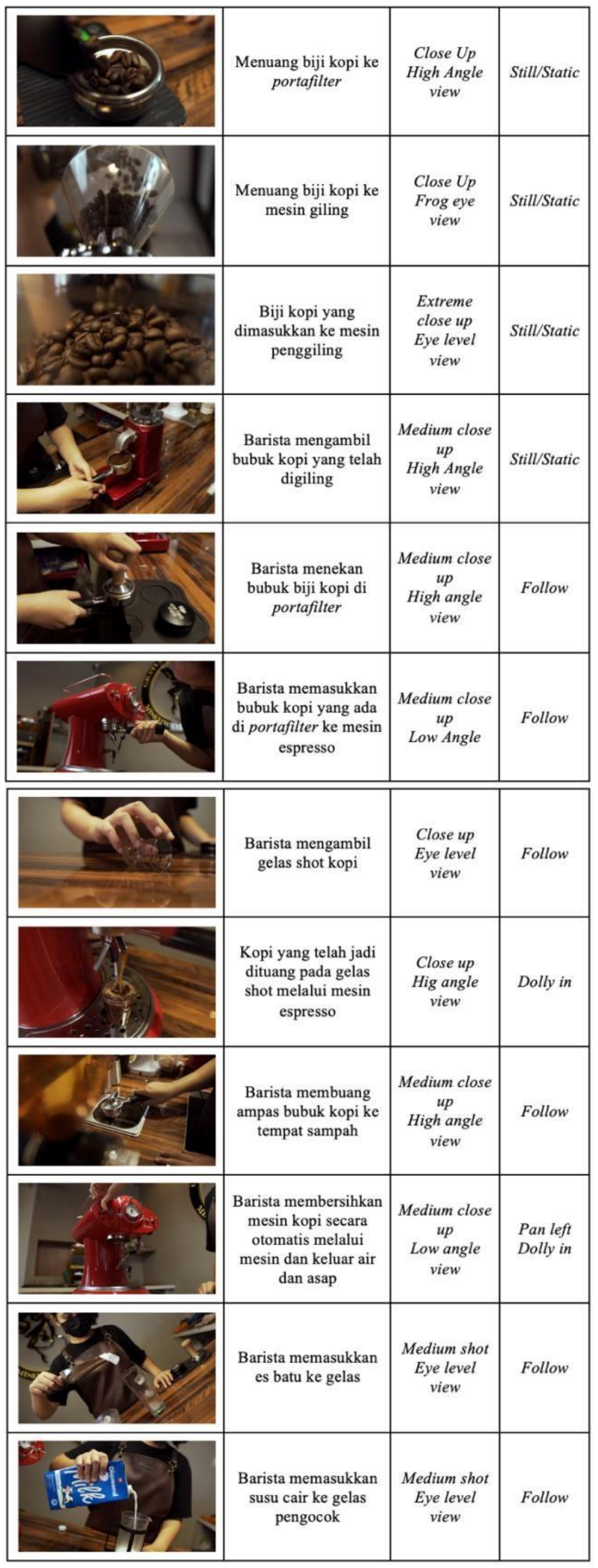

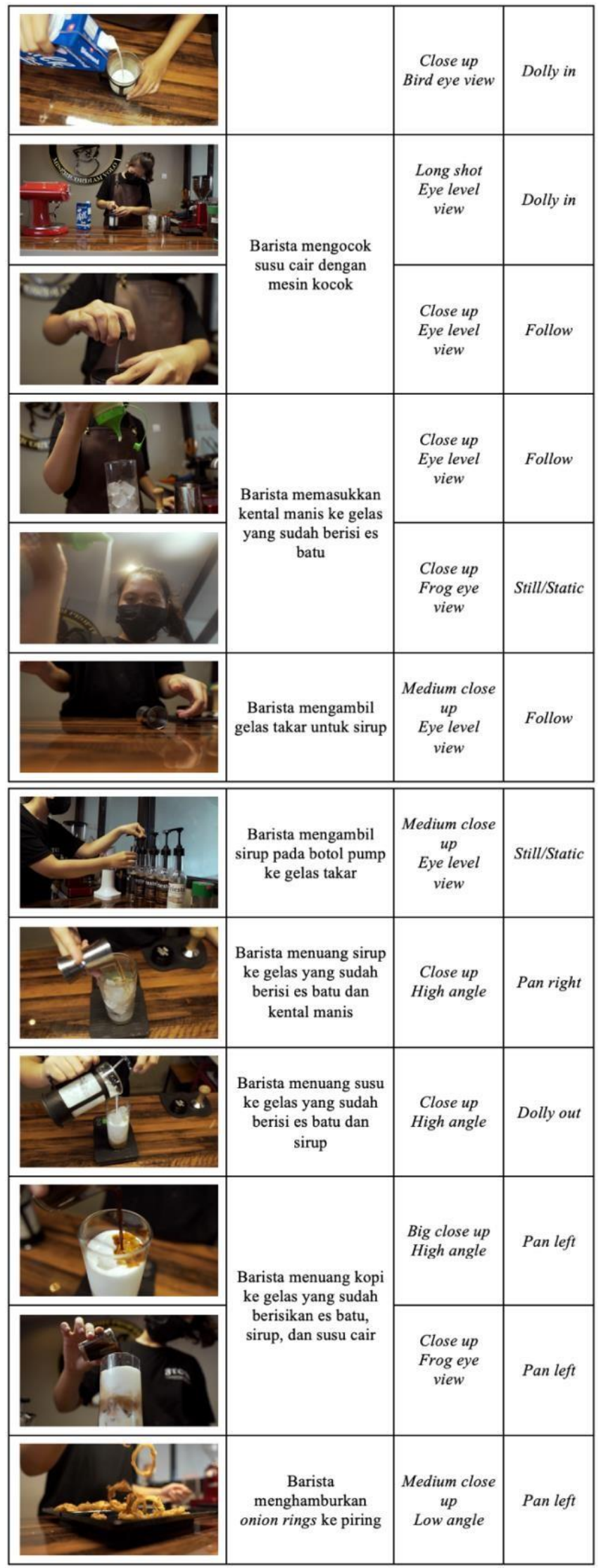




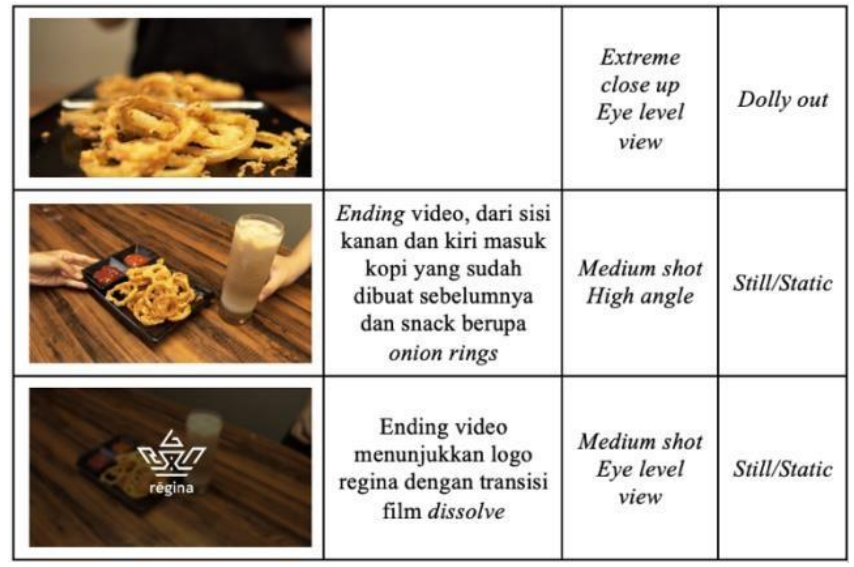

Tabel 5. Cuplikan Scene Hasil Karya Videografi Cinematic

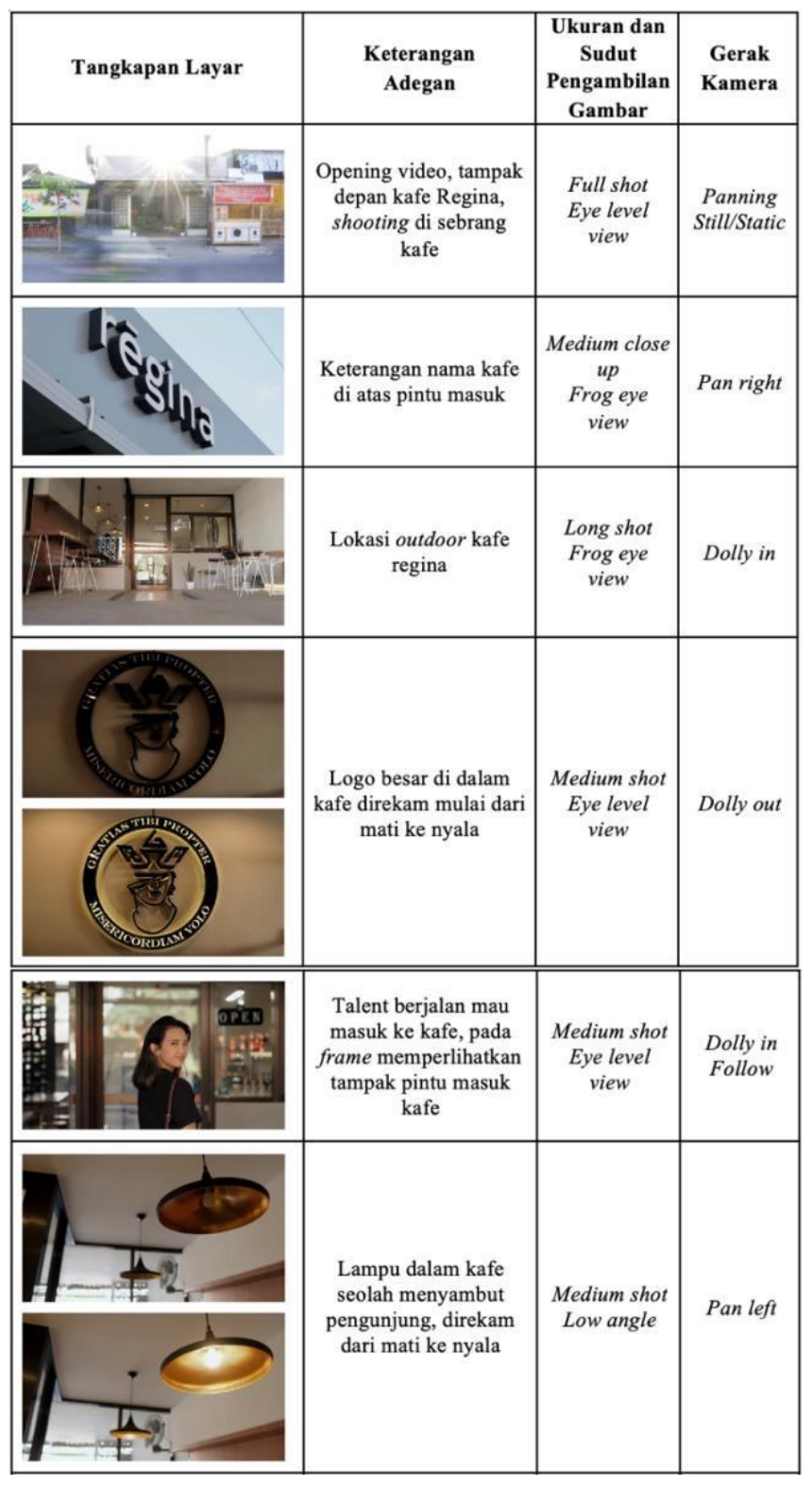

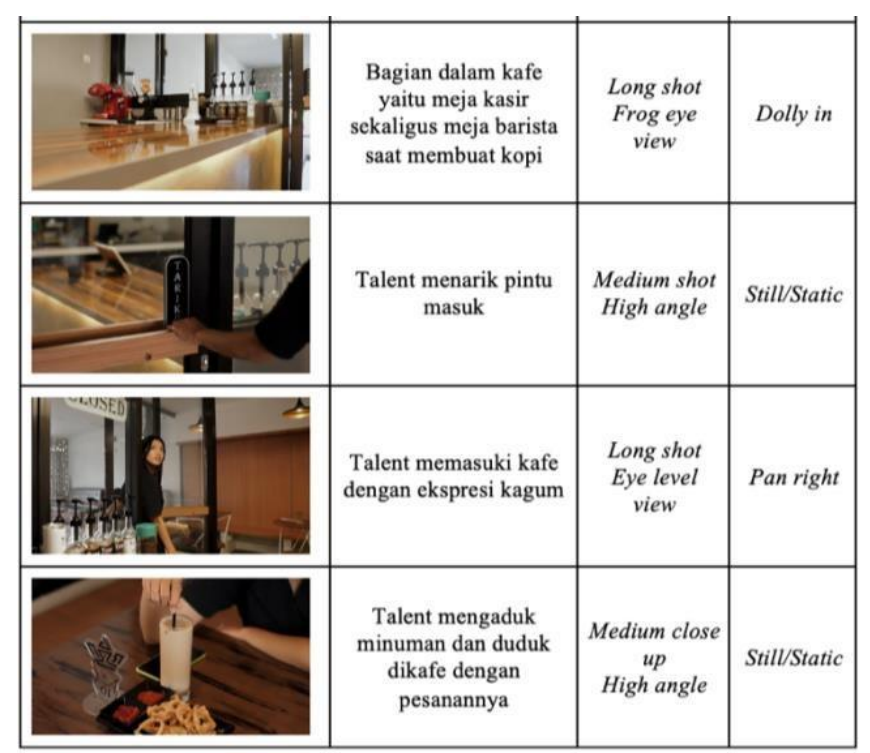

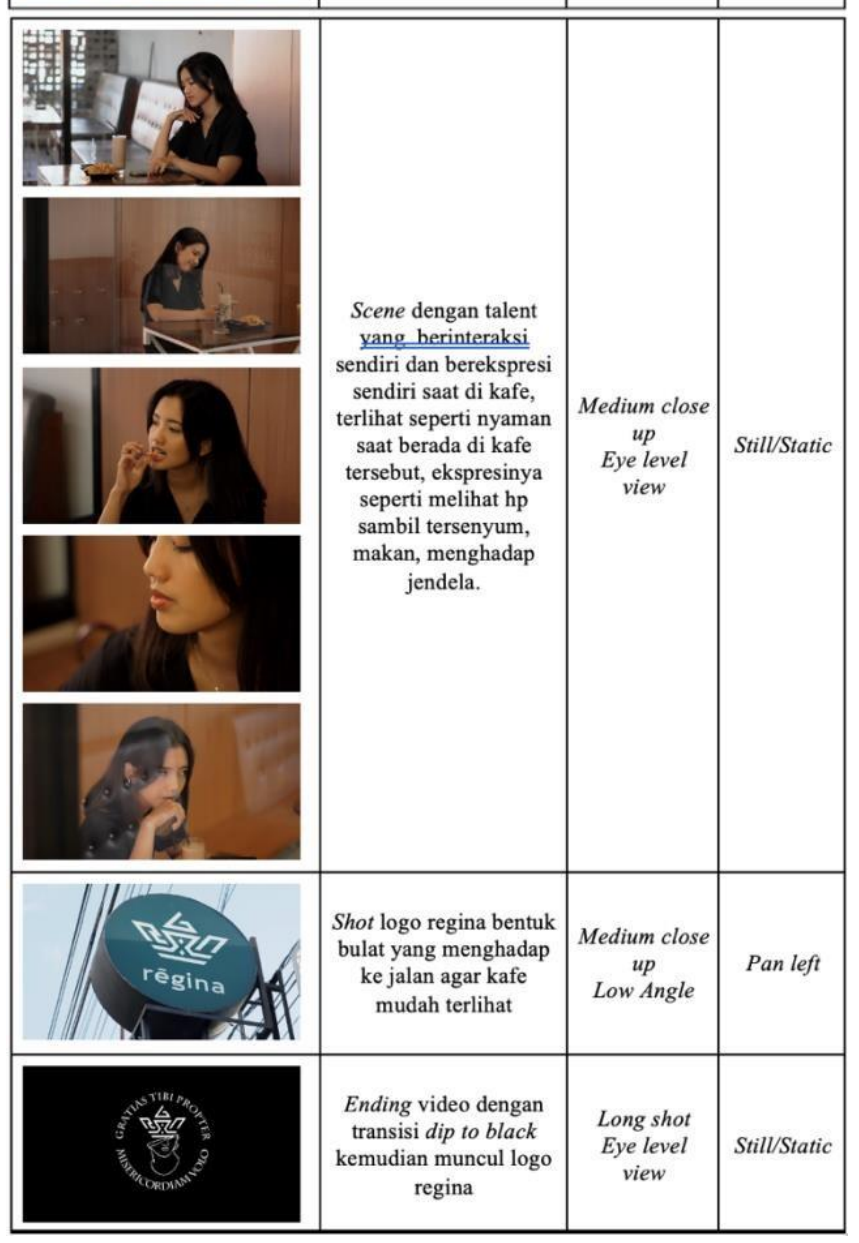

\section{Media Pendukung}

1. Sosial Media

Sosial media merupakan alat untuk mempromosikan konten visual berupa fotografi dan videografi kafe Regina secara 
daring kepada masyarakat Tulungagung dan sekitarnya. Sosial media yang dipilih untuk mempromosikan konten visual ini adalah Instagram. Media sosial ini dipilih karena mampu menampilkan banyak gambar secara detail beserta adanya caption sebagai keterangan dari gambar yang di unggah tersebut.

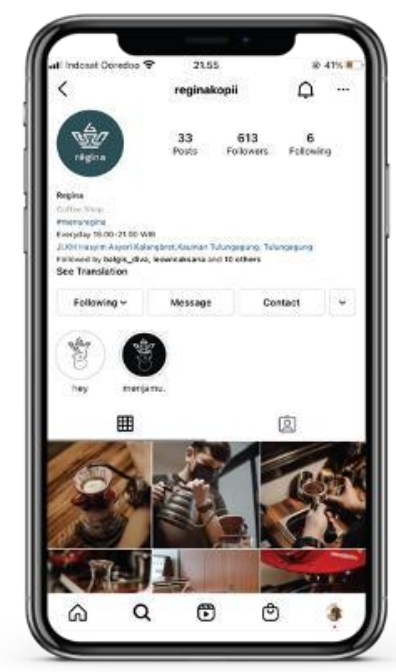

\section{Gambar 7. Sosial Media Instagram Kafe Regina}

\section{T-Shirt}

T-shirt dipilih sebagai media pendukung karena memiliki daya tarik dan ciri khas merchandise dari sebuah kafe atau kedai kopi karena dapat membawa nama brand sebuah kafe karena sering digunakan dan mudah dilihat.

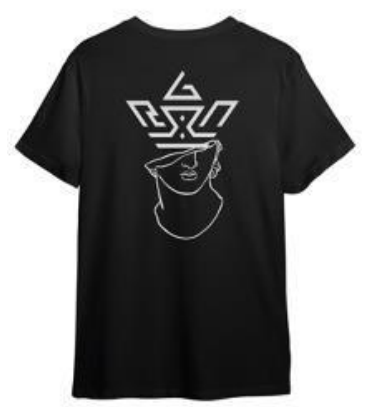

\section{Gambar 8. Merchandise T-Shirt kafe Regina}

\section{Masker}

Karena adanya masa pandemi ini, masker dipilih menjadi salah satu media pendukung karena sangat berfungsi di masa seperti ini dan banyak orang memilih menggunakan masker dengan warna yang gelap supaya tidak kotor.

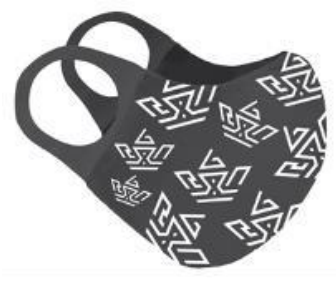

Gambar 9. Merchandise Masker kafe Regina

\section{Totebag}

Totebag adalah tas jinjing dengan desain yang simple, mudah dibawa, dan dapat memuat banyak barang, totebag dipilih karena efisien dan kebanyakan orang membutuhkan totebag dalam keseharian mereka antara untuk sekolah, kuliah, kerja atau hanya sekedar untuk hangout

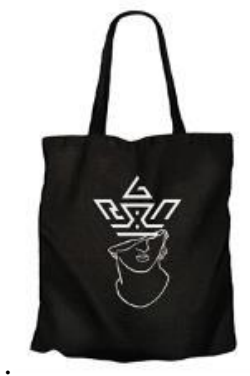

\section{Gambar 1. Merchandise Totebag Kafe Regina}

\section{Sticker}

Totebag adalah tas jinjing dengan desain yang simple, mudah dibawa, dan dapat memuat banyak barang, totebag dipilih karena efisien dan kebanyakan orang membutuhkan totebag dalam keseharian mereka antara untuk sekolah, kuliah, kerja atau hanya sekedar untuk hangout.

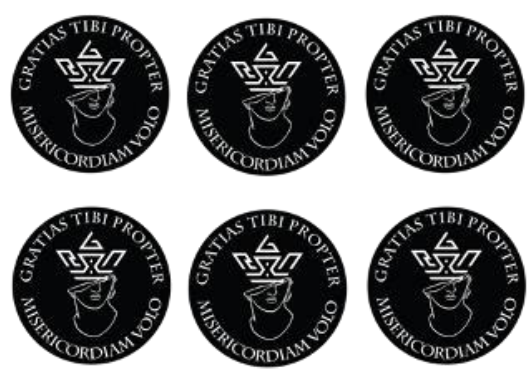

Gambar 1. Sticker kafe Regina

6. Gantungan Kunci Akrilik

Gantungan kunci akrilik memiliki bahan yang bagus dan terlihat berkelas untuk menampilkan logo dari kafe atau produk. Gantungan kunci juga banyak digemari masyarakat 
karena ukurannya yang kecil dan dapat dipakai sebagai gantungan di tas, kunci, kotak pensil, dsb.

\section{Kesimpulan}

Budaya nongkrong di kafe saat ini sudah sangat harafiah sehingga masyarakat berbondong-bondong ingin mulai menjalankan wirausaha dengan membangun sebuah kafe atau kedai kopi. Kopi yang merupakan salah satu minuman favorit banyak masyarakat terutama anak muda selalu menjadi salah satu menu utama pada setiap kafe baru atau bahkan mereka memberi nama usaha mereka dengan tambahan coffe shop, kedai kopi, atau kopi. Peristiwa ini awalnhya terjadi di kota - kota besar yang padat penduduk dan memiliki UMR yang cukup tinggi karena dirasa untuk sekedar nongkrong atau eating out di kafe minimal harus membawa uang Rp 50.000,00 per orang, tetapi seiring berkembangnya jaman, banyak orang yang membangun kafe atau kedai kopi dengan range harga yang dapat dijangkau pelajar/mahasiswa karena harganya yang relative murah. Munculnya satu dua kafe atau kedai kopi dengan harga terjangkau dan memiliki banyak pengunjung yang sangat antusias untuk beli lalu singgah ditempat bersama suatu kelompok atau individual, hal tersebut menyebabkan efek bandgown atau biasa disebut ikut - ikutan, fenomena ini berkaitan dengan adanya trend masa kini atau suatu hal yang sangat menjadi pusat perhatian dan menciptakan peluang besar dalam suatu daerah, contohnya seperti pembangunan kafe atau kedai kopi.

Di Kabupaten Tulungagung dulunya merupakan kota kecil yang tidak banyak wirausaha pemilik kafe, karena cenderung tidak berhasil dikarenakan target market yang kurang memadai dengan budget yang harus dikeluarkan saat mampir ke kafe tersebut. Hingga di akhir tahun 2018 terdapat salah satu kedai kopi yang menjadi pusat perhatian karena merupakan kedai kopi pertama di Tulungagung dan berhasil menarik perhatian para wirausaha di Tulungagung lalu membangun kafe atau kedai kopi dengan konsep yang sama yaitu menjual berbagai macam variant kopi organik dan noncoffe dengan harga yang terjangkau lalu menyediakan tempat nongkrong outdoor yang paling utama. Sehingga seiring tahun berlalu hingga 2021 saat ini, Tulungagung sudah memiliki puluhan kafe / kedai kopi di setiap daerahnya, bahkan banyak wirausaha yang membangun kafe atau kedai kopi yang cukup besar.

Begitu pula dengan apa yang dikerjakan penulis pada tugas akhir ini, kafe Regina yang merupakan salah satu kafe baru dan pertama kali dibangun di area Kecamatan Kauman dan membutuhkan sebuah konten visual untuk mendongkrak usahanya dalam memperkenalkan kafe Regina kepada masyarakat luas di Tulungagung. Saat melakukan wawancara pada beberapa pemilik kafe di Tulungagung yang bisa disebut sebagai kompetitor pula, banyak dari mereka beranggapan bahwa sosial media lah yang sangat membantu dalam pemasaran sebuah kafe, tidak lupa juga adanya konten visual berupa foto dan video yang baik sehingga masyarakat tertarik atau penasaran dengan sesuatu yang baru tersebut. Sehingga disimpulkan bahwa konten visual seperti foto dan video yang di proses dengan baik seperti penggunaan kamera dan fotografer yang tepat dapat membantu wirausaha dalam memasarkan usaha atau produk yang mereka tawarkan, kemudian pada tugas akhir ini, penulis memanfaatkan konten visual fotografi dan videografi sebagai media pendukung pemasaran pada sosial media Instagram kafe Regina. Konten visual yang telah dibuat adalah pengambilan foto - foto makanan, suasana kafe, dan interaksi barista saat melakukan pembuatan kopi, menggunakan teknik zooming yang menghasilkan objek utama terlihat tajam sedangkan background tampak kabur atau blur, lalu teknik field of view supaya dapat melihat objek dari ukuran jarak lensa ke objek, teknik ini berguna untuk melihat seberapa besar atau jauh objek yang masuk ke frame foto, contoh jenis ukuran jauh dekatnya yaitu seperti extreme close up, medium close up, close up, medium shot, full shot, dan long shot, kemudian juga memperhatikan sudut pengambilan gambar yang terdiri dari eye level view, bird eye view, frog eye view dan high angle, tetapi rata - rata penggunaan angle dalam foto makanan adalah eye level view dan high angle.

Kemudian di rancang pula konten visual berupa videografi, terdapat 2 video yang pertama berjenis B-Roll dan yang kedua adalah cinematic video. Pada video B-Roll, terdapat konsep yang menekankan proses pembuatan kopi oleh barista secara rinci, tujuan dari video ini supaya lebih dapat menarik minat masyarakat sekitar saat mengunjungi akun Instagram @ reginakopii dikarenakan video B-Roll merupakan salah satu jenis video promosi dengan konsep yang sangat modern, dan untuk cinematic video akan lebih menekankan suasana kafe dan interaksi seorang pelanggan, cinematic video yang dirancang cenderung memiliki konsep yang calm, slow, cool. Pada video B-Roll menggunakan teknik pengambilan gambar medium close up dan close up dengan teknik kamera follow, yaitu mengikuti pergerakan setiap objek dan point of view yang berarti kamera diam pada satu tempat atau sedikit bergerak tetapi lensa tetap mengarah pada objek yang dituju, juga menggunakan sudut pengambilan gambar eye level view, high angle, dan frog eye view. Kemudian pada cinematic video menggunakan teknik long shot karena bertujuan menunjukkan lokasi/aktivitas kafe Regina dengan teknik kamera dolly yaitu fokus pada 1 objek / 1 area kemudian videographer merekam sambil mundur atau maju, bisa juga disebut zoom in atau zoom out dengan sudut pengambilan gambar eye level view dan high angle. 
Dalam menarik minat audiens pada konten visual fotografi dan videografi untuk kafe Regian ini, maka perancang membuat beberapa media pendukung yang biasa disebut merchandise. Merchandise yang digunakan pada perancangan ini antara lain t-shirt, masker, totebag, gantungan kunci akrilik, dan sticker.

Kopi Kota Malang”, terdapat beberapa saran membangun agar perancangan serupa bisa menjadi lebih baik di masa yang mendatang. Saran ini ditujukan bagi peneliti selanjutnya, bagi Universitas Ma Chung, dan bagi para pembaca buku "Kopi Kota Malang”. Adapun saran-saran tersebut adalah:

Bagi para peneliti yang akan membuat perancangan serupa di masa mendatang diharapkan agar bisa mempelajari teknik follow dalam videografi B-Roll agar dapat menghasilkan video Bakhir ini bahwa para wirausaha cenderung menggunakan sosial media untuk melakukan pemasaran, maka dari itu para pembaca diharap bisa menguasai penataan visual pada sosial media.

\section{DAFTAR PUSTAKA}

Hendrawan, Denny. (2017). Perancangan Visual

Branding Video Smokebelt Garage Berbasis Feature Sebagai Upaya Meningkatkan Brand Loyalty.

Gunawan, Agnes. (2014). Genre Fotografi Yang Diminati Oleh Fotografer Di Indonesia.

Bramantijo, Kesbir. (2011). Perancangan Media Promosi Sitara Indian Restaurant.

Murdaningsih, Retno. Modul Produksi Video Iklan.

Yuliadewi, Lesie. (1999). Mengenal Fotogafi dan Fotografi Desain.

Mara, Armen. (2011). Pemanfaatan Video Sebagai Media Penyebaran Inovasi Pertanian.

Anjaningrum, Widiya. (2018). Pengaruh Entrepreneurship, Business Coaching, Mentoring Dan Komunitas Kreatif Terhadap Kinerja Industri Kreatif.
Roll yang bagus dan dramatis. Kemudian mempelajari dan menerapkan gaya editorial tone dan warna pada foto yang sesuai dengan karakter dan tema yang akan digunakan pada perancangan nantinya. Tone dan warna dirasa sangat bisa meningkatkan komposisi sebuah foto menjadi lebih berkesan saat.

Bagi universitas diharapkan untuk menggunakan media konsultasi online yang seragam antara pembimbing 1 dan 2. Hal ini dimaksudkan agar ketiga pihak (pembimbing 1, pembimbing 2, dan mahasiswa) memiliki kesepahaman yang sama terhadap media yang dirancang. Selain itu, model konsultasi online juga dirasa cukup efektif untuk menyimpan data secara virtual sehingga bisa menjadi data cadangan bila terjadi hal yang tidak diinginkan.

Bagi para pembaca diharapkan bisa menemukan ide - ide yang unik lagi dalam pembuatan dan editing video ataupun foto yang nantinya akan digunakan sebagai media promosi suatu produk atau jasa, seperti yang ada pada tugas

Hartatin, Reni. (2016). Strategi Komunikasi Pemasaran Pekanbaru Just Cake Dan L'cheese Factory Menggunakan Food Photography Pada Media Sosial Instagram Dan Facebook Di Kota Pekanbaru .

Hariyanto, Didik. (2017). Food Photography dan Eating Out di Media Sosial Instagram.

Hendiawan, Teddy. (2019). Penata Kamera Dalam Pembuatan Film Fiksi Berjudul "Tetet Dito".

Edi, Purwanto. (2014). Pusat Seni Fotografi Di Semarang.

Prastowo, A., 2011, Metode Penelitian Kualitatif Dalam Perspektif Rancangan Penelitian, Ar-Ruzz Media, Yogyakarta, Indonesia.

Herlina, Yekti. (2007). Komposisi Dalam Seni Fotografi.

Sanyoto, S. E., 2006, Metode Perancangan Komunikasi Visual Periklanan, Dimensi Press, Yogyakarta, Indonesia. 